International Journal of Current Microbiology and Applied Sciences

ISSN: 2319-7706 Volume 9 Number 7 (2020)

Journal homepage: http://www.ijcmas.com

Original Research Article

https://doi.org/10.20546/ijcmas.2020.907.213

\title{
Assessment of Antagonistic Activity in PGPR Isolates against Alternaria solani causing Early Blight of Potato
}

\author{
Ashutosh Tiwari ${ }^{1}$, Adesh Kumar ${ }^{1 *}$, Minakshi ${ }^{1}$, Shambhoo Prasad ${ }^{1}$, D. K. Dwivedi ${ }^{1}$, \\ N. A. Khan ${ }^{1}$, Arun Kumar ${ }^{2}$, Ved Prakash ${ }^{3}$, Jaipal ${ }^{4}$, Sushil Kumar Singh ${ }^{5}$, \\ Pankaj Kumar ${ }^{6}$ and Abhimanyu Yadav ${ }^{7}$ \\ ${ }^{1}$ Department of Plant molecular Biology and Genetic Engineering, \\ ANDUAT Kumarganj, Ayodhya -224229, India \\ ${ }^{2}$ PBR Agriculture college, Gausganj, Hardoi, India \\ ${ }^{3}$ Department of Soil Science, ANDUAT, Kumarganj, Ayodhya -224229 \\ ${ }^{4} U P C A R$, Lucknow, India \\ ${ }^{5}$ Department of Plant Pathology, ANDUAT Kumarganj, Ayodhya -224229, India \\ ${ }^{6}$ Directorate of Extension, ANDUAT Kumarganj, Ayodhya -224229, India \\ ${ }^{7}$ Department of Soil Science \& Agril Chemistry, P G. College Ghazipur U.P India
}

*Corresponding author

\begin{tabular}{l} 
K e y w o r d s \\
Antagonistic \\
Activity, \\
Alternaria solani \\
Early Blight of \\
Potato \\
\hline Article Info \\
\hline $\begin{array}{l}\text { Accepted: } \\
17 \text { June } 2020 \\
\text { Available Online: } \\
\text { 10 July } 2020\end{array}$ \\
\hline
\end{tabular}

\section{Introduction}

Potato (Solanum tuberosum L.) is one of the world's most important food crops, and is grown in more than 100 countries with different climate conditions including temperate, subtropical and tropical zones. There are several diseases in potato caused by fungi, bacteria, viruses, nematodes and abiotic factors. Among which an early blight caused by Alternaria solani has been known to cause yield losses up to $80 \%$ (Martin, 1986). The disease manifests as leaf spots with dark brown to black concentric ring which later enlarge and result in blighting of leaves and fruits. The dark spot and sunken lesions also 
appear near the base of stem resulting in stunting and girdling of stem. Presently, the management for potato early blight has been done with application of several fungicides. However it may not be sustainable in the longer run as chemical fungicides are known to cause residual toxicity to non-target organism and other environmental hazards. Therefore, recent efforts have been focused on developing ecofriendly; safe long lasting and effective management strategy for early blight of potato through bio control agent such as PGPR. Plant growth promoting rhizobacteria are free living root surface bacteria that have beneficial effects on plant. PGPR has the capability to control a large array of plant pathogens including viruses, bacteria, fungi and nematodes which are causative agents of various diseases in plants. Protection and stimulation of various crop plants by PGPR has been reviewed under both lab and field trial conditions. The antagonistic PGPR have shown potential to suppress the growth of fungal pathogens. It has been reported that Pseudomonas aeruginosan behaves as a strong antagonist against the fungal pathogens Alternaria solani, Macrophomina phaseolina and Fusiarium oxysporum and Pseudomonas florescent inhibits the growth of Rhizoctonia solani in maize crops (Tripathi and Johri, 2002). The antagonistic activity of PGPR is usually accompanied by the production of secondary metabolites (Silva et al., 2001). Most common way for the antagonistic activity is the direct physical contact between the phytopathogens and bio-control agent (Chincholkar and Mukerji, 2007). The PGPR has the ability to synthesize fungal cell wall lysing enzyme (Protease) or hydrogen cyanide which suppress the growth of fungal pathogens and promotes successful compete with pathogens for nutrients or specific niches on the root surface (Cartileaux et al, 2003). Further plant growth promoting endophytic bacteria and plant growth promoting rhizobaceria (PGPR) strains have been developed commercially as a bio-pesticide and tested on several crops to control disease and growth promotion. Keeping all these facts in view, the present study has been planned to assess antagonistic properties in plant growth promoting rhizobacterial strains of potato rhizosphere.

\section{Materials and Methods}

\section{Isolation and Identification of Alternaria solani}

The disease samples were collected from naturally infected potato plants showing characteristics symptoms of early blight. For the isolation of disease causing fungus, the small segments of diseased tissue along with some healthy portion $(5 \times 5 \mathrm{~mm})$ from the infected plants leaves samples were cut with the help of sterilized blade and surface sterilized in $0.5 \%$ sodium hypochlorite $(\mathrm{NaOCl})$ for 1 minute. Surface sterilized plant tissue were rinsed twice by sterilized distilled water for removing the traces of Sodium hypochlorite, dried on filter paper and plated on Petri plates containing Potato Dextrose Agar medium (PDA) amended with 100 $\mu$ g/ $\mathrm{ml}$ of streptomycin sulphate (Pryor and Michailides, 2002). Petri plates were incubated at $28^{\circ} \mathrm{C}$ temperature in B.O.D. incubator for 7 days. During incubation, the fungal growth was appeared on the petriplates. The cultural characters of the field isolates of Alternaria solani

\section{Isolation and maintenance of bacterial native antagonists from potato rhizosphere}

Rhizospheric soil from healthy potato plants were collected from different locations. The identified bacterial antagonists, viz., Pseudomonas spp. and Bacillus spp. were isolated by serial dilution technique using nutrient agar mediam. The bacterial antagonists were further purified on their 
respective media and compared with the isolates maintained in laboratory.

\section{Determination of antagonistic effect in PGPR against Alternaria solani}

The antagonistic activity of each selected bacterial isolate against Alternaria alternate was studied by using a dual culture plate assay (Sharma et al., 2003). A loop-full of 48 hrs old culture was spotted in the centre of the potato dextrose agar plate and $6 \mathrm{~mm}$ disc of pre grown phyto-pathogenic fungi inoculated on both sides of the plate. The plates with only fungal disc without bacterial streaks served as control. All in vitro antagonism assays were done in triplicate. The percent inhibition was determined after incubating for 7 days at $28^{\circ} \mathrm{C}$. The percentage growth inhibition was calculated using the following calculation:

$$
\mathrm{I}=\frac{\mathrm{C}-\mathrm{T}}{\mathrm{C}} \mathrm{X} 100
$$

Where, I= Per cent inhibition, $\mathrm{C}=$ Growth in control, $\mathrm{T}=$ Growth in treatment

\section{Results and Discussion}

\section{Isolation and Identification of Alternaria solani}

Early blight of potato phytopathogen was isolated from infected leaf of potato plant. The phytopathogen produced dark brown on PDA plate. The abundant sporulations were seen in the isolate. Margin was regular with aerial mycelium topography and septate. Hyphae were short swollen much branched sclerotia were $5.5 \mathrm{~mm}$ in size. Based upon these characters, the phytopathogen was identified as Alternaria solani.

The isolated fungal mycelial growth was transferred on fresh PDA and purified. The phyto-pathogen was further transferred to fresh PDA and also maintained on slants for further use.

\section{Isolation of rhizospheric bacteria}

Twenty four rhizobacterial isolates were isolated from potato rhizospheric soil samples by using serial dilution method. Isolates were selected on the basis of distinctive morphology, size, shape and color of the bacterial colony and location of the soil sample. All the isolates were tentatively labeled as PRS 01 to PRS 24 and maintained on nutrient agar slants with periodic transfer to fresh medium for future application,

\section{Determination of antagonistic effect in PGPR against Alternaria solani}

Twenty four PGPR isolates were tested for their efficacy in inhibiting growth of Alternaria solani fungus on PDA media. Out of which, the isolate PRS 5, PRS 15, PRS 16, and PRS 23 (Table.1) showed inhibitory effect on the pathogen and recorded with bigger clearing zones on the medium plate. Similar finding were observed by Abdalla et al.., (2017) who reported forty five Bacillus isolates were tested for their efficacy in inhibiting growth of Alternaria alternata. Out of which twenty seven showed clear inhibition zone. This suggests that the 27 isolates of Bacillus displayed antagonism against Alternaria alternata in-vitro due to the production of antimicrobial compounds. While in our study, fourteen isolate i.e. RPS $(1,2,4,6,7,12,14,17,18,19,20,21,22$ and 24) also found positive and showed medium inhibitory effect on the test fungus. The isolate $3,8,9,10,11$ and 13 showed low inhibitory effect with minimum clear zone on the media plates against test fungus. Eight strains of Pseudomonas fluorescens isolates from various agro ecological zones or crop's rhizosphere like tomato, moong, brinjal, rice, chilli, mustard, chirchida found most effective 
with the highest antagonistic activity against two fungal pathogens and showed maximum inhibition of mycelial growth of Alternaria alternate $(48.13 \%)$ and Rhizoctonia solani $(68.23 \%)$ as reported by Maurya et al., (2014).

Table.1 Antagonistic effect of PGPR isolates against Alternaria solani

\begin{tabular}{|l|c|c|}
\hline Isolate No. & Inhibition zone (cm.) & Inhibition $\mathbf{( \% )}$ \\
\hline PRS 01 & 2.0 & 65 \\
\hline PRS 02 & 2.4 & 79 \\
\hline PRS 03 & 2.0 & 65 \\
\hline PRS 04 & 2.4 & 79 \\
\hline PRS 05 & 2.9 & 95 \\
\hline PRS 06 & 0.5 & 15 \\
\hline PRS 07 & 1.5 & 42 \\
\hline PRS 08 & 1.0 & 32 \\
\hline PRS 09 & 1.0 & 31 \\
\hline PRS 10 & 1.3 & 42 \\
\hline PRS 11 & 2.5 & 82 \\
\hline PRS 12 & 2.2 & 65 \\
\hline PRS 13 & 1.5 & 49 \\
\hline PRS 14 & 2.0 & 65 \\
\hline PRS 15 & 2.8 & 92 \\
\hline PRS 16 & 2.0 & 65 \\
\hline PRS 17 & 2.4 & 79 \\
\hline PRS 18 & 2.2 & 65 \\
\hline PRS 19 & 2.2 & 72 \\
\hline PRS 20 & 2.5 & 82 \\
\hline PRS 21 & 1.4 & 45 \\
\hline PRS 22 & 1.5 & 49 \\
\hline PRS 23 & 2.5 & 82 \\
\hline PRS 24 & 1.3 & \\
\hline & & 42 \\
\hline
\end{tabular}

The rhizospheric bacterial isolates of BTcotton showed inhibitory effect against Alternaria macrospora, the causal organism of Alternaria leaf blight of cotton and the high antifungal activity was shown by rhizospheric isolates RLS19 (91.43\%) and followed by PLS52 (88.52\%) (Raut and Hamde 2016.). Devi and Mohan 2015 found that the bacterial isolates of Achromobector, Alternaria xylosoxidans (LK391696) was tested against Alternaria solani under in-vitro condition. The Alternaria solani was inhibited by $85 \%$. In the present study, PRS 5 showed 95\% inhibition that is highest among all the potato rhizosphere isolates. The other researchers also carried out similar experiments as different strains of Pseudomonas which could inhibit as much as $31.5 \%$ mycelium growth of Alternaria solani (Sundaramoorthy and Balabaskar 2012). When results of 'previous researchers compared to our findings, our finding found more superior than the others as because it might be due to antifungal potential shown by these different isolates was due to production of volatile metabolites, diffusible metabolite, siderophore and hydrolytic enzymes. 


\section{References}

Abdalla, A. O.,Bibi, S. and Zhang, S. 2017. Integration of Chitosan And Plant Growth- Promoting Rhizobacteria to Control Papaya Ringspot Virus and Tomato Chlorotic Spot Virus Arichives of phytopathology and plant protection 4 (4)1-11

Abdalla, S.A., Algam, S.A., Ibrahim, E.A., and El Naim, A.M. 2014. In vitro screening of Bacillus isolates for biological control of early blight disease of tomato in shambat soil. World Journal of Agricultural Research, 2(2): 47-50

Cartileaux, P., Kumar, S., Malik, J.A., Berger, J.D. and Nayyar, H. 2003. Plant growth promotion abilities of bacterial isolates using potato as indicator plant. Journal of Biotechnology and Bio-safety 1(2): 1-10.

Chincholkar, S.B. and Mukerji, K.G. 2007. Biological control of plant diseases. The Haworth Press, Inc., Binghamton, NY. $426 \mathrm{p}$.

Devi, K.S. and Mohan, V 2015. Antagonistic potential and plant growth promoting traits of Achromobacter Xylosoxidans isolated from tannery sludge sample. Annals of Biological Research 6 (6) 21-25

Martin, E.L. 1986. Studies on growth condition of the tomato alternaria leaf spotcausing Alternaria solani L. The Bioscan 8(1): 101-104.

Maurya, L., Brahmeswara, M.V., Raju, S.C. and Reddy, S.N. 2015. In-vitro experiment for evaluation of efficacy of different PGPR isolates. International Journal of Current
Microbiology Applied Science, 6(7): 1798-1806

Pryor, B.M., and Michailides, T.J.2002. Morphological, pathogenic, and molecular characterization of Alternaria isolates associated with Alternaria late blight of pistachio. Phytopathology, 92(4): 406416.

Raut LS and Hamde V S. 2016 Screening of Antifungal Potential of Rhizospheric Isolates against Alternaria Leaf Blight Disease of Bt-cotton in vitro. International Journal of Current Microbiology Applied Science 5 (8): 769-784

Sharma, A., Johri, B. N., Sharma, A. K. and Glick, B. R. 2003. Plant growth promoting bacterium Pseudomonas sp. strain GRP3 influences iron acquisition in mung bean (Vignaradiata L. wilzeck). Soil Biololgy and Biochemistry 35: 887-894.

Silva, E.F., Schammass, E.A., Oliveira, G.C.X. and Ando, A. 2001. Morphoagronomic diversity in American potato species. Brazilian archives of Boilogical Technology 51(1): 94-104

Sundaramoorthy S, Balabaskar P. 2012. Consortial effect of endophytic and plant growth promoting rhizobacteria for the management of early blight of tomato incited by Alternaria solani. Journal of Plant Pathology and Microbiology 3 (7): 1-5

Tripathi, P. and Johri, T. 2002 In vitro evaluation of antagonistic properties of Pseudomonas corrugate. Microbiological Research 163(3): 329-336

\section{How to cite this article:}

Ashutosh Tiwari, Adesh Kumar, Minakshi, Shambhoo Prasad, D. K. Dwivedi, N. A. Khan, Arun Kumar, Ved Prakash, Jaipal, Sushil Kumar Singh Pankaj Kumar and Abhimanyu Yadav. 2020. Assessment of Antagonistic Activity in PGPR Isolates against Alternaria solani causing Early Blight of Potato. Int.J.Curr.Microbiol.App.Sci. 9(07): 1851-1855. doi: https://doi.org/10.20546/ijcmas.2020.907.213 